\title{
Total dose infusion of fractionated iron dextran complex in management of anaemia in antenatal cases
}

\author{
Manjunath $S^{1}$, Veena $\mathbf{H ~ C}^{2}$ \\ ${ }^{1}$ Assistant Professor, Department of Obstetrics \& Gynecology, Hassan Institute of Medical Science, Hassan, \\ Karnataka, India \\ ${ }^{2}$ Post Graduate, Department of Physiology, Navodaya Medical College, Raichur, Karnataka, India
}

Received: 8 June 2013

Accepted: 15 June 2013

\author{
*Correspondence: \\ Dr. Manjunath S, \\ E-mail: hsogmanju@gmail.com
}

(C) 2013 Manjunath S et al. This is an open-access article distributed under the terms of the Creative Commons Attribution Non-Commercial License, which permits unrestricted non-commercial use, distribution, and reproduction in any medium, provided the original work is properly cited.

\begin{abstract}
Background: Iron deficiency anemia is common clinical manifestation in pregnancy. It can be easily prevented or corrected by early diagnosis and proper treatment successfully. This study was done to know the efficacy, effectiveness, rise in hemoglobin level and adverse effects of newly available low molecular weight iron dextran complex.

Methods: A prospective clinical trial was conducted in randomly selected 50 antenatal women who attended the OPD of OBG department and were moderately anemic and fulfilled the inclusion criteria of the study

Results: All the 50 women were moderately anemic with hemoglobin level between 7-9 gm\%. After total dose infusion of low molecular weight fractionated iron dextran complex, hemoglobin level was measured at 4 weeks and at term. The mean hemoglobin level rose to $9.5 \mathrm{gm} / \mathrm{dl}$ by 4 weeks after infusion and to $11.53 \mathrm{gm} / \mathrm{dl}$ at term, which was statistically significant $(\mathrm{p}<0.0001)$. Only one patient developed non-cardiac chest pain during the test dose and two patients developed urticaria during total dose infusion.

Conclusion: The study showed a statistically significant increase in hemoglobin level after total dose infusion of low molecular weight iron dextran complex with a good safety profile and minimal hospital stay.
\end{abstract}

Keywords: Iron deficiency anemia, Pregnancy, Hemoglobin, Low molecular weight fractionated iron dextran, Total dose Infusion

\section{INTRODUCTION}

Anemia in pregnancy is a global problem. In India and its neighbouring countries the prevalence of anemia in pregnancy ranges from $40 \%$ to $90 \% .^{1}$ In Karnataka observed the incidence of iron deficiency anemia to be $58.1 \%$. According to the community based NFHS-2 study incidence of anemia in pregnant women was $48.6 \%{ }^{2}$ Overall incidence of anemia in pregnancy is categorized as, (a) Any anemia $48.6 \%$ (b) Mild anemia 20.9\%, (c) Moderate anemia $29.9 \%$ and (d) Severe anemia $2.9 \%$ in pregnant women. ${ }^{3}$

Anemia is directly and indirectly the cause of maternal mortality and morbidity, intra-uterine growth retardation, pre-term delivery and peri-natal mortality and morbidity. ${ }^{4}$
Anemia can be easily prevented or corrected or corrected by early diagnosis and proper treatment successfully, but it is still a major health problem in India. WHO guidelines recommended that all pregnant women in developing countries should receive routine daily supplementation of iron $60 \mathrm{mg}$, and folic acid $400 \mu \mathrm{g}$.

Govt. of India, NNAPP-1970, ICMR-4989, recommends $100 \mathrm{mg}$ of elemental iron $+50 \mu \mathrm{g}$ of folic acid in second half of pregnancy for 100 days. In moderately anemic patient, along with oral iron preparations, two doses of parenteral intramuscular iron dextran $(250 \mathrm{mg}$ each) are recommended. ${ }^{5}$ The major problem with oral iron therapy in its classic ferrous form is poor tolerability and up to $40 \%$ adverse reaction rate. ${ }^{6}$ Parenteral administration of iron is necessary under certain circumstances and may be 
suitable under following situations like, inability to tolerate the side effects of orally administered iron, inflammatory bowel disease, peptic ulcer, non compliance with oral regimens, documented iron malabsorption and pregnancies near term. ${ }^{1}$

The newly available parenteral iron dextran is a highly fractionated form of low molecular weight iron dextran which has been shown to be safer as compared to that of the conventional parenteral iron preparations ${ }^{7}$ and it help to avoid unnecessary blood transfusions in late pregnancy. ${ }^{8}$ Various controlled clinical trials have established the excellent safety profile of highly fractionated low molecular weight iron dextran as compared to that of the conventional preparations. ${ }^{7}$ So we have taken this study, to assess the efficacy, effectiveness and side effects of fractionated low molecular weight iron dextran complex in replenishing the iron store and in increasing hemoglobin level for the management of moderate iron deficiency anemia in pregnancy.

\section{METHODS}

The prospective clinical trial was conducted at AIMS college hospital for the duration of $1 \frac{1}{2}$ year after obtaining ethical clearance from the concerned ethical committee. It included 50 patients with iron deficiency anemia between 22 wks to 34 wks of gestation. All patient of pregnancy with iron deficiency anemia, hemoglobin level between $7 \mathrm{gm} \%$ to $9 \mathrm{gm} \%$, willing for the parenteral therapy and likely to come for follow up were included in study. After obtaining informed written consent, detailed obstetric and menstrual history was obtained. General physical condition was assessed followed by per-abdominal examination and they were admitted to the hospital as in-patients for a day dose infusion as a single dose or in 2 divided doses. Those allergic to parenteral iron, anemia of acute onset, anemia at term, anemia due to haemoglobinopathy [Thalassemia], hemolytic anemia, aplastic anemia megaloblastic anemia, severe anemia [Hb $<7 \mathrm{gm} \%$, intolerance to intra-venous administration of iron at the first $0.5 \mathrm{ml}$ of test dose, unwilling to participate in the study were excluded from the study.

The required total dose has to be individually adapted according to the total iron deficit calculated by the following formula: Hemoglobin in g/l -- Body weight (kg) $\times$ (target $\mathrm{Hb}-$ actual $\mathrm{Hb}$ ) g/l x $0.24+\mathrm{mg}$ iron for store. Therapy thus should aim at not only replenishment of hemoglobin, but of iron stores as well. Hemoglobin was determined by cell counter method at first visit and every 4 wks after total dose infusion. The total amount of fractionated low molecular weight iron dextran required is determined by calculating from the formula.

Oral iron was discontinued prior to administration. By keeping bed side anti-anaphylactic drug tray containing Inj. Avil, Inj. Betnasol, Inj. Hydrocortisone, Inj. Deriphylline, Inj. Epinephrine and Inj. Adrenaline, $0.5 \mathrm{ml}$ of fractionated low molecular weight iron dextran complex corresponding to $25 \mathrm{mg}$ of iron diluted in $10 \mathrm{ml}$ of normal saline was infused intravenously slowly for about half an hour. If no untoward reaction occurs, total dose infusion was done. That total amount of dose up to $20 \mathrm{mg}$ per $\mathrm{kg}$ body weight is added aseptically to the $500 \mathrm{ml}$ of sterile normal saline or $5 \%$ Glucose solution and is infused intravenously over 4$6 \mathrm{hrs}$. The rate of infusion is increased progressively to $45-$ 60 drops per min. Patients are observed carefully during the infusion and $1 \mathrm{hr}$ after the completion of the procedure. Total dose can also be transfused in divided doses, 2 times apart a week intravenously as per above mentioned method. The pregnant anemic women were given the infusion and observed for the side effects, and necessary measures were taken.

After infusion, on each visit, thorough Obstetrical examination was done along with clinical assessment of pallor and $\mathrm{Hb}$ estimation by cell counter method was carried out. $\mathrm{Hb}$ was repeated at every 4 wks till term by the same method and the rise or change in $\mathrm{Hb}$ level was determined till term by comparing the values.

\section{Statistical Analysis}

The obtained data of increase in $\mathrm{Hb} \%$ after total dose infusion was analyzed using repeated measures of ANOVA followed by Tukey-Kramer multiple comparison tests. A pvalue less than 0.05 were considered as significant. Data was analyzed by using software Minitab v14.0

\section{RESULTS}

50 pregnant women who were moderately anemic were assigned for treatment group. In all pregnant women age, gestational age and maternal weight was recorded.

The study group of pregnant women had a mean hemoglobin level of $7.55 \mathrm{gm} / \mathrm{dl}$ and all the women were showing microcytic hypochromic blood picture.

Table 1 revealed that $42 \%$ women in this study belonged to the age group of $18-20$ years followed by $26 \%$ women were in the age group of $21-23$ years and only $2 \%$ women belonged to age group of $30-32$ years.

Table 1: Data representing age of study group.

\begin{tabular}{|lll|}
\hline Age & Number & Percentage \\
\hline $18-20$ & 21 & 42 \\
\hline $21-23$ & 13 & 26 \\
\hline $24-26$ & 12 & 24 \\
\hline $27-29$ & 03 & 6 \\
\hline $30-32$ & 01 & 2 \\
\hline Total & 50 & 100 \\
\hline
\end{tabular}

At the time of diagnosis the hemoglobin levels of 24 primigravida in the study group was mean value of 8.01 $\mathrm{gm} / \mathrm{dl}$. Four weeks after total dose infusion the mean $\mathrm{Hb}$ 
level increased by $1.35 \mathrm{gm} / \mathrm{dl}$ and at term by it was increased by $3.92 \mathrm{gm} / \mathrm{dl}$, whereas for 26 multigravida in the study group were mean $\mathrm{Hb}$ was $7.45 \mathrm{gm} / \mathrm{dl}$. Four weeks after total dose infusion the mean $\mathrm{Hb}$ level increased by $1.67 \mathrm{gm} / \mathrm{dl}$ and at term by $4.08 \mathrm{gm} / \mathrm{dl}$.

Table 2: Data representing increase in $\mathrm{Hb}$ gm\% in primigravida and multigravida.

\begin{tabular}{|lllll|}
\hline Parameter & $\begin{array}{l}\text { No of } \\
\text { subjects }\end{array}$ & $\begin{array}{l}\text { Hb gm\% } \\
\text { before } \\
\text { infusion }\end{array}$ & $\begin{array}{l}\text { Increase in } \\
\text { Hb gm \% } \\
\text { after } 4 \text { weeks } \\
\text { of transfusion }\end{array}$ & $\begin{array}{l}\mathrm{Hb} \\
\text { gm\% } \\
\text { at } \\
\text { term }\end{array}$ \\
\hline Primigravida & 24 & $7-8.6$ & 1.35 & 3.92 \\
\hline Multigravida & 26 & $7-8.4$ & 1.67 & 4.08 \\
\hline
\end{tabular}

Table 3: Data representing increase in $\mathrm{Hb}$ gm\% with gestational age.

\begin{tabular}{|lllll|}
\hline $\begin{array}{l}\text { Parameter } \\
\text { (weeks of } \\
\text { gestation) }\end{array}$ & $\begin{array}{l}\text { No of } \\
\text { subjects }\end{array}$ & $\begin{array}{l}\text { Hb gm\% } \\
\text { before } \\
\text { infusion }\end{array}$ & $\begin{array}{l}\text { Increase in } \\
\text { Hb gm \% } \\
\text { after } 4 \\
\text { weeks of } \\
\text { transfusion }\end{array}$ & $\begin{array}{l}\text { Hb } \\
\text { gm } \%\end{array}$ \\
\hline 20 to 25 & 16 & 7.35 & 1.61 & 3.88 \\
\hline 26 to 29 & 18 & 7.6 & 1.85 & 4.37 \\
\hline 30 to 34 & 16 & 7.68 & 1.56 & 3.55 \\
\hline
\end{tabular}

The statistical analysis of the increase in hemoglobin levels after total dose infusion showed significant $(\mathrm{p}<0.0001)$ increase levels at both $4^{\text {th }}$ weeks after infusion and at term. Out of fifty pregnant women who were given total dose infusion, only three showed very minimal adverse reactions. Urticaria was seen in one woman, two women showed rashes along with itching and one women developed non-cardiac chest pain. No women had any severe adverse reactions.

\section{DISCUSSION}

Iron deficiency anemia is the most prevalent nutritional deficiency affecting more than 2000 million people approximately $20 \%$ of the world population. Pregnancy increases the maternal need for iron to supply foetal iron needs, which cannot be met by normal dietary intake and requires supplementation by oral or parental route. Commonly antenatal women are advised to take oral iron therapy. But parenteral iron therapy is preferred in women who are moderately anemic, who are near term and who do not tolerate oral iron parental therapy is preferred. Intramuscular parental therapy required repeated injections, which may be not compiled by the patients, as it requires repeated visits to the health center; therefore intravenous total dose infusion is preferred as it is one-time procedure with comparable benefits as the intramuscular injections.

Table 4: Efficacy of fractionated low molecular weight iron dextran complex in replenishing the iron store.

\begin{tabular}{|c|c|c|c|c|c|c|c|}
\hline & 0 week & 4 weeks & At term & $\begin{array}{l}\text { F- } \\
\text { value }\end{array}$ & p-value & $\begin{array}{l}\text { Tukey's multiple } \\
\text { comparison }\end{array}$ & $\begin{array}{l}\text { Average } \\
\text { increase in } \\
\mathrm{Hb} \text { gm \% }\end{array}$ \\
\hline \multirow{3}{*}{$\mathrm{Hb}$ gm $\%$} & \multirow{3}{*}{$\begin{array}{l}7.57 \pm \\
0.54\end{array}$} & \multirow{3}{*}{$9.21 \pm 0.81$} & \multirow{3}{*}{$11.3 \pm 1.86$} & \multirow{3}{*}{144.6} & \multirow{3}{*}{$\mathrm{P}<0.0001$} & 0 vs 4 weeks, $p<0.001$ & 1.64 \\
\hline & & & & & & 0 vs at term, $\mathrm{p}<0.001$ & 3.73 \\
\hline & & & & & & 4 weeks vs term, $p<0.001$ & 2.09 \\
\hline
\end{tabular}

High molecular weight iron-dextran can be administered in both intramuscular and intravenous route contains $50 \mathrm{mg}$ of elemental iron per $\mathrm{ml}$. It is the parenteral preparation currently in general use. It is a complex of ferric oxy hydroxide with dextran of 500-700 Daltons in a viscous solution containing $50 \mathrm{mgs} / \mathrm{ml}$ of iron.

Fractionated low molecular weight iron dextran complex $^{9,10,11}$ is a novel parenteral iron formulation has entered the Indian market, being promoted as an effective and safe alternative to conventional iron preparation in management of iron deficiency anemia. It is a dark, slightly viscous, sterile liquid complex of ferric hydroxide and highly fractionated low molecular weight dextran for intravenous or intramuscular use. Each $\mathrm{ml}$ contains the equivalent of $50 \mathrm{mg}$ of elemental iron (as an iron dextran complex) and approximately $0.9 \%$ sodium chloride in water for injection.
Low molecular weight iron dextran complex given intravenously as total dose infusion has shown evident increase in the hemoglobin levels in the present study.

The rise in the hemoglobin levels was statistically significant at 4 weeks after infusion and at term. Only 3 side effects were observed due to total infusion of low molecular weight iron dextran complex, and none were fatal. Patient compliance was assured, as it was mostly a one-time procedure. Only 15 required two divided doses one week apart depending on the degree of anemia. Intravenous infusion of low molecular weight iron dextran complex appears to be an effective way of correcting moderate anemia in pregnancy. In nutshell, intravenous infusion of low molecular weight iron dextran complex as a total dose infusion appears to be an effective way in correcting moderate anemia in pregnancy. 
The study has showed following benefits:

$$
\begin{aligned}
\text { i. } & \text { Significant increase in hemoglobin level. } \\
\text { ii. } & \text { Good safety profile. } \\
\text { iii. } & \text { Minimal hospital stay. }
\end{aligned}
$$

High therapeutic efficiency, wide safety margin with minimal accidental overdose risk, very low toxicity, excellent patient compliance, minimal adverse reaction, not only replenishment of hemoglobin but of iron stores as well are the properties of when rapid substitution is required because of severe iron deficiency Low molecular weight iron dextran. It is required for rapid substitution in severe iron deficiency. It is one of the perfect haematinic to treat iron deficiency in pregnancy and to reduce maternal morbidity and mortality and a new vista towards safe motherhood.

\section{Funding: None}

Conflict of interest: None declared

Ethical approval: The study was approved by the Institutional Ethics Committee

\section{REFERENCES}

1. Usha Krishna et al., Anemia in Pregnancy: Pregnancy at risk current concepts: The Federation of obstetrics and Gynecological Society of India: Chapter 40: 4th Edition 2001: pp: 229-332.

2. Toteja G.S., Padam Singh. Iron deficiency anaemia: Micronutrient Profile of Indian Population: Indian Council of Medical Research: New Delhi - 2004: pp: 556.

3. Toteja G.S., Padam Singh. Pregnant and lactating women current status: Iron deficiency anaemia: Micronutrient Profile of Indian Population Chapter
4.1.3: Indian Council of Medical Research: New Delhi -2004: pp 32-34.

4. Jai B Sharma et al.: A prospective randomized study of pregnancy outcomes and hematolOgical responses to Iron treatment in moderately anaemic pregnant women: AM J Nutr 2004: 70: pp: 116 -22.

5. John Studd. Iron deficiency Anaemia: Nutritional anaemia during pregnancy is non- industrialized countries: progress in obstetrics and gynecology Chapter 7: Vol.15.2003:pp:107-110.

6. Sharma J.B., Soni D., Oxidative stress in pregnancy - Role of iron therapy: oral iron therapy and risk of free radicals: Obs and Gynac: vol. VI No.12: Dec. 2001: pp 705-706.

7. Richard A. et al., Parenteral iron formulation: A comparative toxicological analyses and mechanism of cell injury: American Journal of Kidney diseases: Vol. 40: No.1 July 2002: pp: 90-103.

8. Hallak $M$ et al.: Supplementing iron intravenously in pregnancy: A way to avoid blood transfusion: Feb. 1997 42(2): pp: 99-103.

9. Fleter R., Lazarus JM, Gage J., Chertow G.M.: Suspected iron dextran -related adverse drug events in Hemodialysis patient: AM J Kidney Dis 37 (4) 2001: 743 - 749.

10. Ahlmen J., Vaage - Nilnen O: Safety evaluation of iron (Ferriecit $®$, DexferrUm $®$, Infed () from 21,060,000 Doses Administered 1.V in the US 1990-2000: Nephrol Dial Transplant 17 (Suppler) 2002: 133, \#M305.

11. Zager R.A., Johnson A.C.M., Hanson S.Y., Wasseh H. Parenteral Iron Formulations: A Comparative Toxicological Analysis and Mechanisms of Cell Injury. AM J Kidney Dis 2002;40(1):90-103.

DOI: $10.5455 / 2320-1770 . i j \operatorname{rcog} 20130918$

Cite this article as: Manjunath S, Veena HC. Total dose infusion of fractionated iron dextran complex in management of anaemia in antenatal cases. Int $\mathbf{J}$ Reprod Contracept Obstet Gynecol 2013;2:355-8. 